\title{
ANALYSIS OF TECHNICAL CONDITION OF LOCAL ROADS DRAINAGE IN THE CZESTOCHOWA REGION
}

doi: 10.2478/cqpi-2019-0034

Date of submission of the article to the Editor: 02/04/2019

Date of acceptance of the article by the Editor: 15/05/2019

\section{Zbigniew Respondek ${ }^{1}$ - orcid id: 0000-0003-0204-5061 \\ ${ }^{1}$ Czestochowa University of Technology, Poland}

\begin{abstract}
Local roads (district and municipal) play an important role in the road network, especially in rural areas. In recent years, these roads have been largely repaired, which was often associated with the construction of new infrastructure. One of the basic conditions of maintaining the quality of road works is the proper construction or renewal of drainage devices. Errors in this area result in lower durability of the road pavement. It is equally important to maintain these devices later in a good technical condition, which requires spending appropriate funds from local government budgets. The aim of the study presented in the article was to determine the current technical condition of drainage of local roads in the Czestochowa region and to identify the most frequent design and implementation errors, resulting in a rapid loss of functionality of drainage devices. They were based mainly on in situ studies carried out in the area of an exemplary rural municipality. Errors resulting in the lack of continuity of drainage, or the danger of a rapid loss of its functionality are shown with real examples. It was found that despite the shortcomings described, in recent years the technical condition of drainage of local roads has improved, which is related to the systematic overhaul of local roads (including the construction of sidewalks) and the local government's perception of the importance of road drainage problem.
\end{abstract}

Keywords: road drainage, drainage devices, quality of road works, road maintenance.

\section{THE IMPORTANCE OF LOCAL ROAD DRAINAGE}

In the context of their function in the road network, all district and municipal roads, with the exception of access roads within compact buildings (housing estates), can be called "local roads". Local roads are characteristic for rural areas, although many of their sections run within the administrative boundaries of cities. These roads have two important functions. First of all, they constitute a basic communication system for short-distance trips and a connection to the network of provincial and national roads. Secondly, in rural areas, they function as a street - this type of development is characteristic for many regions of Poland, including Czestochowa region. In the last twenty years local governments have implemented many road investments improving 
the quality of life in rural areas: most importantly, sanitary sewage is being built, which is most often connected with the renewal of road pavement and building of sidewalks. One of the important factors determining the quality of road works, in the context of durability of the pavement and road safety, is the proper construction or renewal of drainage devices (Gudelis-Taraszkiewicz, 2009). Rainwater, related drainage and seepage waters, as well as ground waters act on the road core. The destructive effect of water is manifested primarily by: penetration of rainwater into gaps (cracks in the pavement) and destruction of the aggregate bituminous cover, disintegration of the surface after freezing, weakening of the road body by seeping waters, corrosion of the stone foundation under high groundwater level, road scarps erosion and a decrease in the adhesion of vehicle tires to the road surface.

All these effects are so dangerous for road pavements that the main task of designers and road managers should be to protect the road from the damaging effects of water. This task is carried out firstly by preventing water flowing from the adjacent area into the road core, secondly by taking the water flowing from the road surface and as quickly as possible leaving it outside the road structure (Edel, 2000; Szyling and Pacześniak, 2004; Zalecenia projektowania, 2008; Kalantari et al., 2014).

The aim of the research presented in the article was to determine the current technical condition of elements of drainage of local roads in the Czestochowa region and to identify the most common design and performance errors resulting in a reduction in drainage efficiency. The research was carried out in one of the communes of the Czestochowa district. A visual assessment (Szklarczyk, 2014) of drainage elements was carried out within local roads. The results of previous study from 2016 (Respondek, 2017) and archival author's photographic documentation were also used.

\section{TYPES OF DRAINAGE DEVICES ON LOCAL ROADS}

The first element of drainage is the road surface. This surface should be even, tight and have appropriate slope - on the straight segment, transversal bilateral drop (roof section), at least $2 \%$, on the arc, one-sided slide towards the center of the arch. The minimum longitudinal fall is $0.3 \%$ (Zalecenia projektowania, 2008).

Ditches and culverts are commonly used on local roads as dewatering devices. Maintaining the patency of these devices requires continuous maintenance (cleaning). Ditches are used commonly, despite the fact that they are difficult to maintain and unfavorable in terms of road safety. In addition to roadside ditches, draining ditches that transmit water outside the road core, for example to rivers, are also important. If the surface of the road core is shaped in the form of a small embankment and the adjacent land is permeable, a "natural drainage" can be used, i.e. the water is allowed to spread over the surrounding area. Natural drainage should not be used in built-up areas.

In the absence of a sidewalk, water from the road surface is usually transmitted to ditches or into the ground through an unpaved roadside. Along the sidewalk, simple gutters are mostly used, i.e. formed at the connection of road surface and the curb, less often triangular or oval gutters. Water from the surface is discharged into ditches through connections located under the sidewalk or, in the absence of ditches along the pavement, the so-called underground drainage is used - inlets, inspection chambers and pipes under the road pavement draining water to receivers located 
further away (Mieszkowski, 2006; Kowacki, 2015; Majer, 2016). An exemplary system of dewatering devices in built-up areas is shown in Fig. 1.

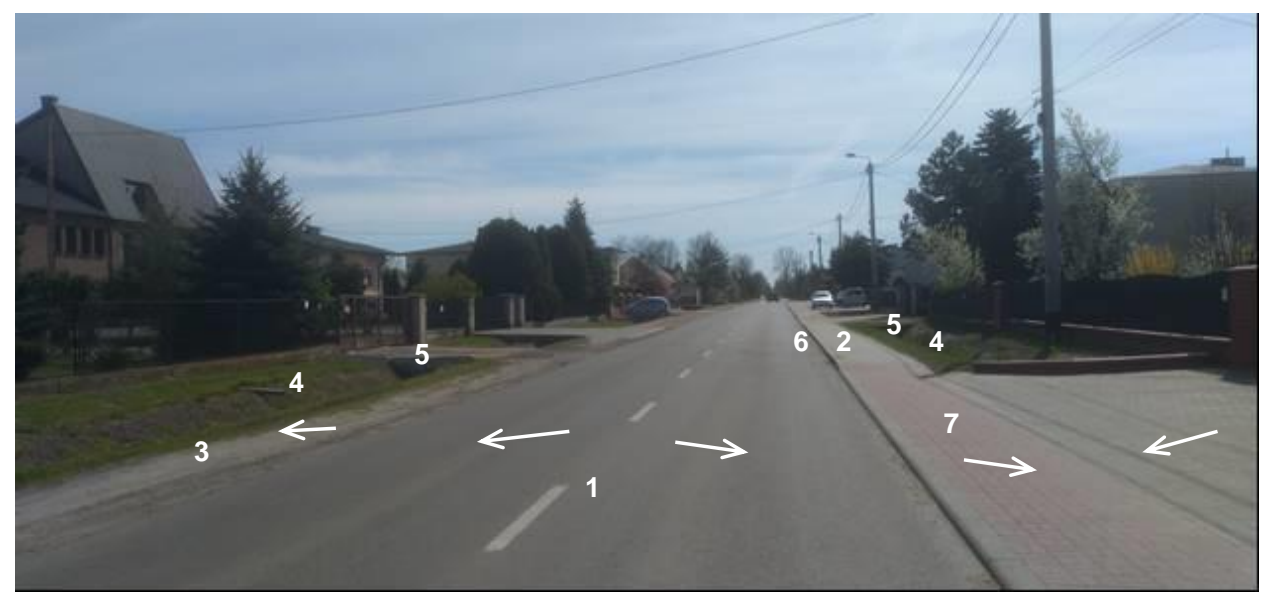

Fig. 1. Elements of drainage in built-up area, arrows indicate the direction of water runoff: $1-$ road surface with a „roof-like slope”, 2 - sidewalk, 3 - unpaved roadside, 4 - ditch, 5 - culvert, 6 - near-curb gutter, 7 - exit with lowered curb

\section{TECHNICAL CONDITION OF THE DRAINAGE OF LOCAL ROADS ON EXAMPLE OF A RURAL COMMUNE}

The technical condition of the drainage of local roads within the sample municipality in the Czestochowa district was determined according to the rating scale (good, satisfactory, unsatisfactory, bad) and the guidelines of the SOPO instruction (System oceny, 2008). The summary results of the assessment are presented in Table 1. "Condition of drainage devices" included assessment of ditches and culverts and gutters, if any. The sign " + " means a good or satisfactory rating, i.e. the ditches are not overgrown, open culverts, gutters without sludge, proper water flow. "Condition of roadside" included the assessment of unpaved roadsides. The sign "+" means a good or satisfactory rating, i.e. the roadsides are not overstated, too low or rutted. The percentage values presented in Table 1 are the sum of the length of sections having a given feature in the total length of the road.

All district roads within the borders of the analyzed commune were assessed -54.5 $\mathrm{km}$. As the elements on both sides of the road were assessed independently, the overall length of the assessed roadsides and elements of drainage is $109 \mathrm{~km}$, except that the percentages were calculated separately for built-up areas and undeveloped areas. The assessment was also made of $35.7 \mathrm{~km}$ (71.4 km of elements) of major municipal roads - the unpaved roads and sections that did not matter in the communication between the villages were omitted.

Data for 2019 was determined based on a visual assessment carried out "in situ", for 2012 based on the analysis of panoramic photographs ("street view") from June 2012 available on the Google Maps web platform (https://www.google.com/maps/). For district roads, rates were also determined based on analogous studies carried out in 2016 in the same scope (Respondek, 2017). 
Table 1

Summary assessment of the technical condition of drainage devices and roadsides

\begin{tabular}{|l|l|l|l|l|l|l|}
\hline \multirow{2}{*}{ Year } & \multicolumn{1}{|c|}{ Condition of drainage devices } & \multicolumn{2}{c|}{ Condition of roadside } \\
\cline { 2 - 7 } & + & - & \multicolumn{1}{c|}{ none } & \multicolumn{1}{c|}{+} & - & sidewalks \\
\hline District roads - built-up areas $42.9 \mathrm{~km}(85.8 \mathrm{~km}$ of devices) \\
\hline 2012 & $29.7 \%$ & $41.2 \%$ & $29.0 \%$ & $29.5 \%$ & $54.6 \%$ & $15.9 \%$ \\
\hline 2016 & $43.1 \%$ & $38.1 \%$ & $18.8 \%$ & $30.2 \%$ & $46.1 \%$ & $23.7 \%$ \\
\hline 2019 & $55.9 \%$ & $28.3 \%$ & $15.8 \%$ & $37.3 \%$ & $34.0 \%$ & $28.7 \%$ \\
\hline Municipal roads - built-up areas $25.6 \mathrm{~km}(51.2 \mathrm{~km}$ of devices) \\
\hline 2012 & $38.7 \%$ & $25.2 \%$ & $36.1 \%$ & $28.5 \%$ & $55.7 \%$ & $15.8 \%$ \\
\hline 2019 & $68.2 \%$ & $10.8 \%$ & $21.0 \%$ & $41.7 \%$ & $33.5 \%$ & $24.8 \%$ \\
\hline District roads - undeveloped areas $11.6 \mathrm{~km}(23.2 \mathrm{~km}$ of devices $)$ & \\
\hline 2012 & $8.6 \%$ & $50.0 \%$ & $41.5 \%$ & $21.8 \%$ & $78.2 \%$ & $0.0 \%$ \\
\hline 2016 & $13.3 \%$ & $47.8 \%$ & $38.9 \%$ & $44.9 \%$ & $55.1 \%$ & $0.0 \%$ \\
\hline 2019 & $15.9 \%$ & $46.5 \%$ & $37.6 \%$ & $55.8 \%$ & $44.2 \%$ & $0.0 \%$ \\
\hline Municipal roads - undeveloped areas $10.1 \mathrm{~km}(20.2 \mathrm{~km}$ of devices) \\
\hline 2012 & $1.2 \%$ & $17.8 \%$ & $80.9 \%$ & $22.3 \%$ & $77.7 \%$ & $0.0 \%$ \\
\hline 2019 & $8.7 \%$ & $20.8 \%$ & $70.5 \%$ & $29.0 \%$ & $67.5 \%$ & $3.5 \%$ \\
\hline
\end{tabular}

Based on the results presented in Table 1, it was found that the technical condition of drainage and roadsides in the analyzed terrain is systematically improving, especially in built-up areas. The most important factor affecting this improvement is the large scope of road repairs and reconstructions carried out by local governments after Poland's accession to the European Union. Road repairs and reconstructions were most often connected with the implementation of sewage systems in rural areas with the use of subsidies from EU funds. Before 2004, there were virtually no sidewalks in the analyzed terrain. When analyzing data from Table 1, it should be remembered that sidewalks in rural areas are mostly carried out on one side of the road - it can be noticed that more than half of local road routes have a paved roadside. The implementation of pavements not only improves the safety of pedestrians, but on this occasion also drainage devices are built. It is worth noting that even in 2012, over $30 \%$ of roads in built-up areas lacked any dewatering. Such deficiencies can always result in the danger of water being deposited on the surface, its contamination and flooding of areas near the road.

Of course, the realization of drainage devices results in the necessity of their conservation, as will be discussed later. During the research, sections were also identified, the status of which, for example in 2012, was rated good, and in later years as bad, due to progressive contamination.

Therefore, the current technical condition of dewatering consists of many factors that operate within a given time frame. In the following, examples of errors and negligence that had a negative impact on the technical condition of drainage in the analyzed terrain were analyzed. Positive examples of corrective and maintenance actions are also given. 


\section{EXAMPLES OF ERRORS COMMITTED DURING PLANNING AND REALIZATION OF ROAD WORKS}

Construction or renovation of drainage is usually the action performed when replacing the road pavement and construction of sidewalks. The errors made in the analyzed terrain consisted in particular of:

- failure to maintain the continuity of drainage,

- ditch deepening without overhauling culverts,

- using inlets and lateral pipes with too small cross-sections,

- using inappropriate solutions at exits to the property,

- errors in connecting drainage devices with each other,

- improper construction of unpaved roadsides.

Failure to maintain the drainage continuity results in long water storage in ditches or on surrounding terrain. The material of the road core is washed or rinsed. Exposed to long water effect, the stone foundation corrodes faster, which reduces the durability of the pavement (Fig. 2).
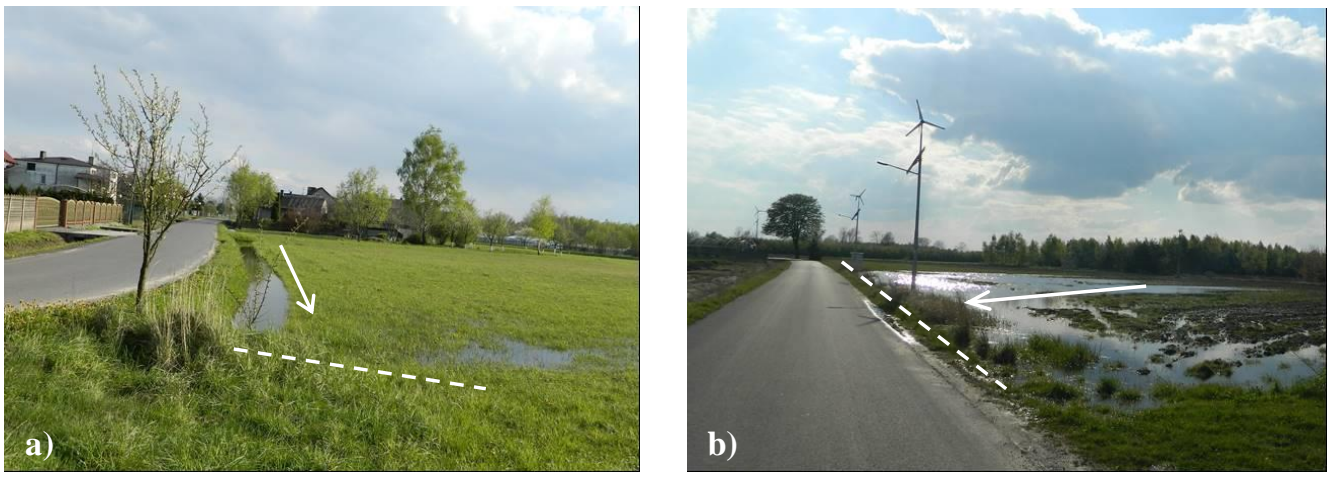

Fig. 2. No continuity of drainage: a) ditch without outlet, b) no culvert prevents water from floating to the other side of the road core

Fig. 3 shows the effects of a faultily performed procedure consisting in the so-called "ditch cosmetics". Deepening the ditches has led to the situation that the bottom of the ditch is below the line of old culverts, which causes the retention of water. It also happens that the culverts are clogged or simply do not exist. Despite the maintenance operations carried out, the technical condition of the drainage was described as bad in such sections.
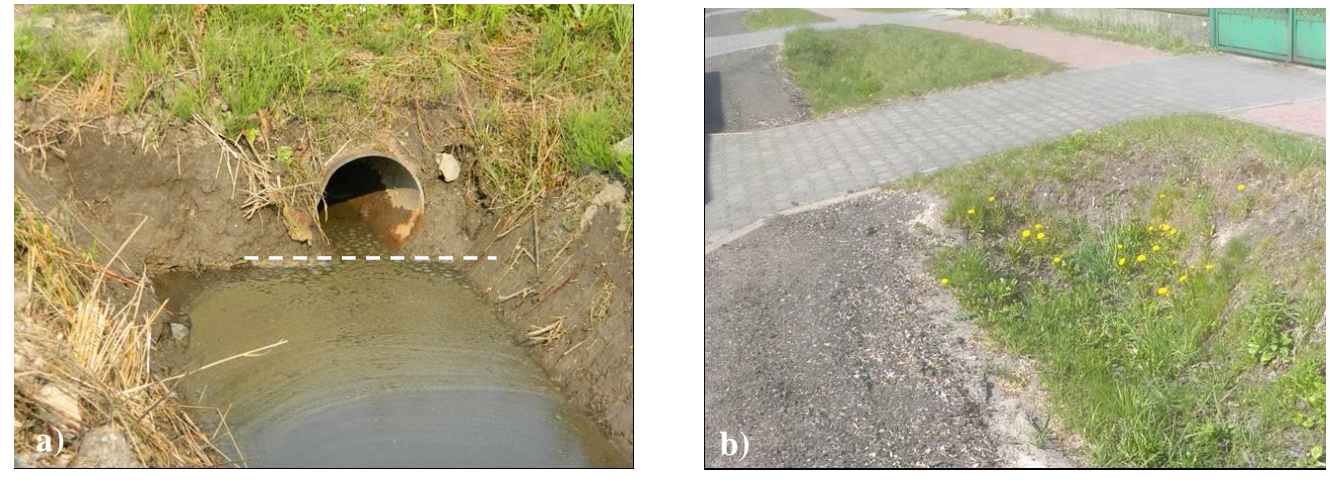

Fig. 3. Errors in the renovation of ditches: a) low ditch bottom, b) no culverts 
Fig. 4a shows the drainage of water from the near-curb gutter into the ditch by means of a inlet with a lateral conduit located under the surface of the sidewalk. Too small cross-sections of these devices have proven to almost clog them up. After a few years, the error was removed: new inlets with lateral pipes $\phi 150 \mathrm{~mm}$ were installed (Fig. 4b) - it required dismantling parts of the pavement, i.e. incurring unnecessary costs.
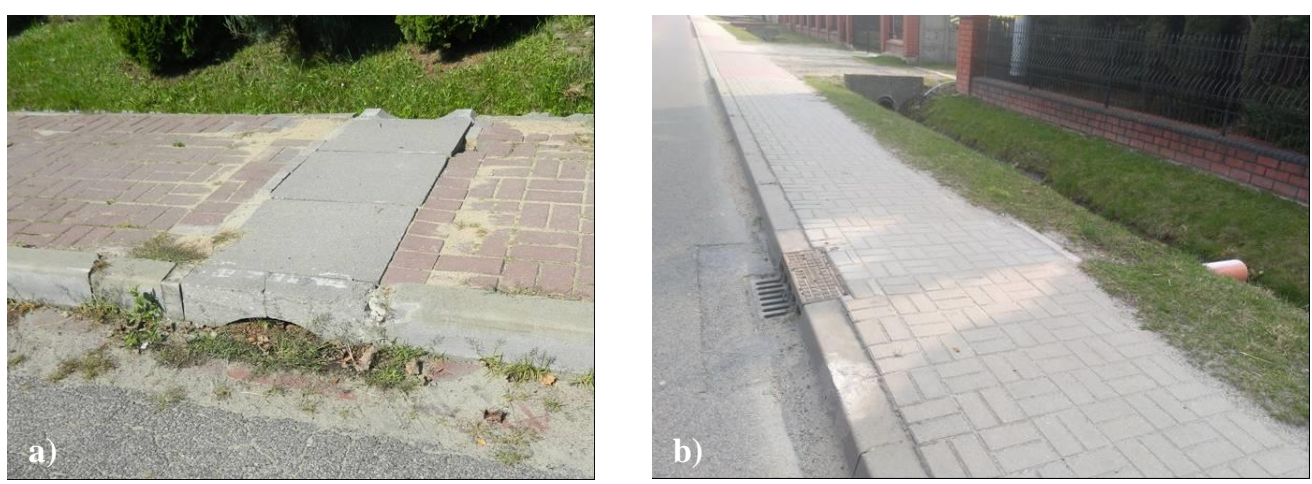

Fig. 4. Draining water with a conduit: a) cross-sections are too small, b) after replacement

As already mentioned, a sidewalk is usually laid on one side of the road - on the other side lie gutters or unpaved roadside. Near the sidewalk, a high curb and a lowered curb on exits are most often used. This solution has some drawbacks: firstly, the longitudinal equality of the pavement is disturbed, secondly the surface at the curb is silted, which causes puddles to form more often. If a triangular gutter is used instead of a curb, another problem occurs. If the design stage did not include solutions facilitating passing at exits and at the same time not worsening conditions of water runoff, residents "facilitate" passage on their own, often doing it inappropriately (concreting of the gutter, filling with slag, placing wooden, steel or even bricks, Fig. 5). Because of this the gutter is quickly silted up. The technical condition of drainage in this section was described as unsatisfactory.
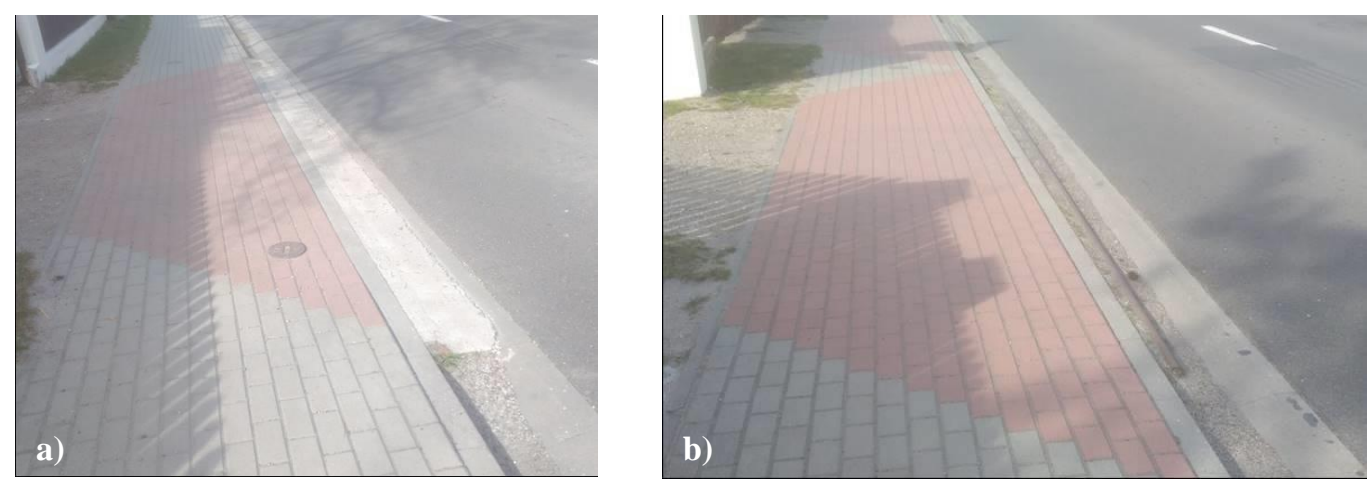

Fig. 5. "Facilitation of passage" through triangular gutter: a) concreting, b) steel pipes

Fig. 6 presents a case of an evidently incorrect connection of drainage devices with each other. The oval gutter was moved away from the roadway, and an unpaved aggregate roadside was laid between the gutter and the roadway. Virtually after the first rainfall, the gutter was contaminated with stone material and after a few years it became practically invisible. 

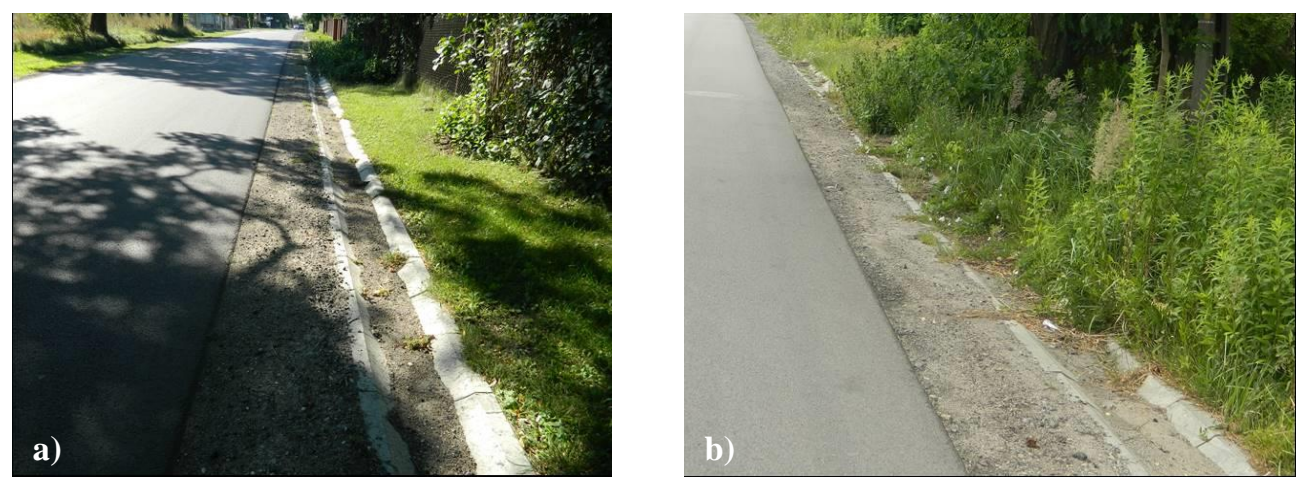

Fig. 6. Incorrect positioning of an oval gutter: a) shortly after construction, b) after two years

A common mistake in the construction of unpaved roadsides is the use of poor quality stone material, with a high proportion of clay components and insufficient densification. Such roadside, soaked in water, is very susceptible to rutting (Fig. 7a). Another common mistake is the incorrect cross slope for the roadside on the outside of the road curve (Fig. 7b).
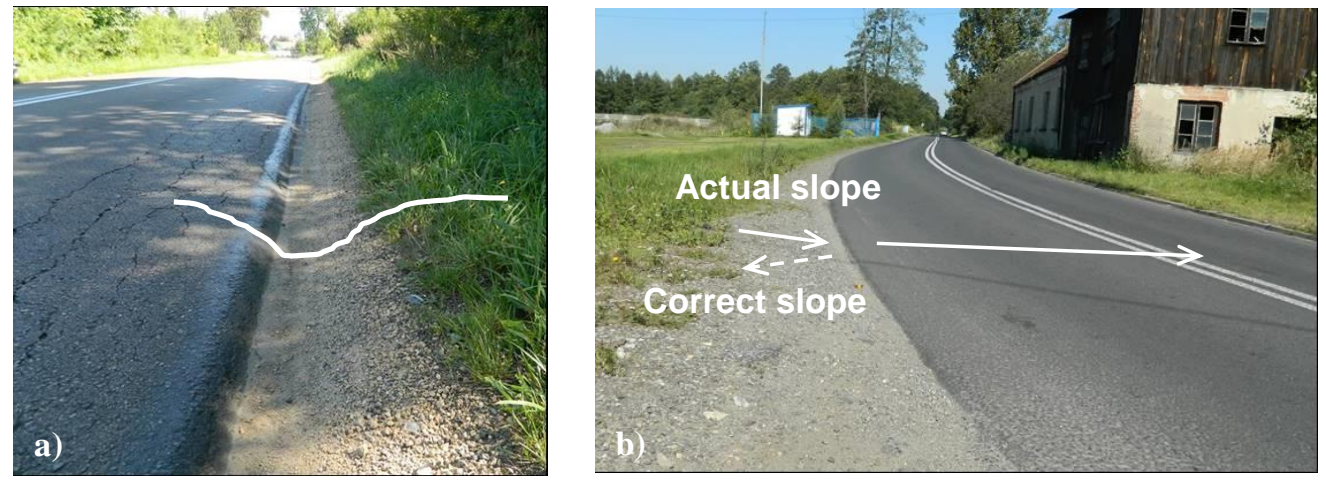

Fig. 7. Roadside: a) rutted and swollen, b) improperly inclined

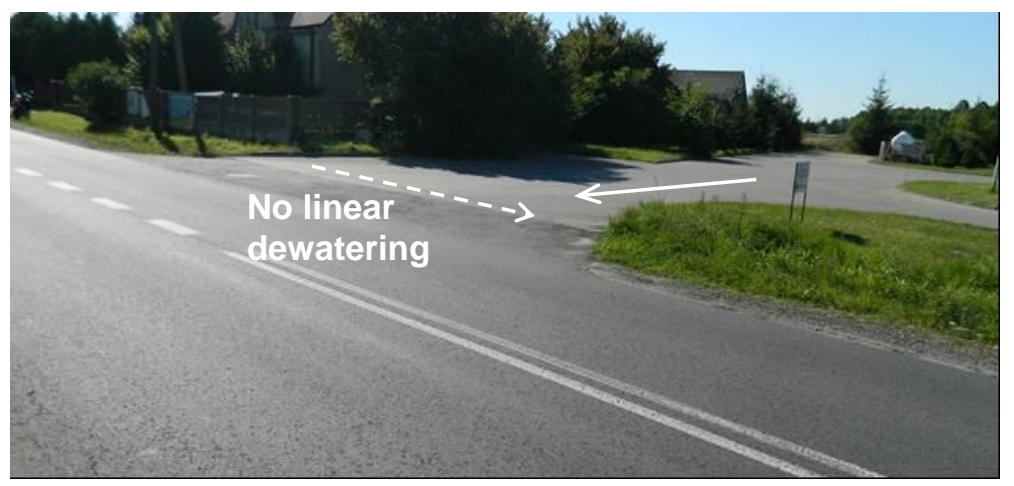

Fig. 8. Possibility of covering the road surface with water from the paved area - the problem would be partially solved by using a box-gutter at the exit

Recently, another factor affecting dewatering has also become apparent. Paving has become common, usually with concrete cubes, not only in areas such as commercial facilities, but also private properties. In case of heavy rain or thaw, the water runs down the paved surfaces almost immediately, which, if not properly taken, can lead to flooding and silting the surface of the roads below (Fig. 8). In this context, it seems 
advisable to make more common using collection systems around buildings to collect rainwater for use (Karelová et al., 2013).

\section{PROBLEMS RELATED TO MAINTAINING PROPER TECHNICAL CONDITION OF DRAINAGE}

The following agents have a negative influence on the technical condition of drainage:

- silting of ditches, culverts and gutters,

- overgrowth of ditches and roadsides with vegetation,

- slipping (erosion) of road scarps,

- swelling of roadsides caused by freezing and overgrowing.

The described phenomena occur quickly, causing frequent repetition of maintenance operations: mowing, cleaning of silted devices, profiling of ditch slopes and roadsides. In built-up areas, mowing ditches and unclogging culverts is basically in the interest of the owners of adjacent properties - these are done or not, depending on the awareness and involvement of the residents. Most of the tasks, however, are the responsibility of local authorities, which must plan and finance these efforts (Jaarsmaand Van Dijk, 2002; Galvão Ribeiro et al., 2019). It was noticed that in recent years local governments more often perceive the importance of the problem, and the actions taken contribute to the improvement of the technical condition of drainage on many sections of roads, although the scope of these activities is still insufficient.

An example of a rapid loss of functionality of uncleaned drainage elements is shown in Fig. 9. It is worth noting the total blockage of the outlet of underground drainage, which makes it ineffective and the sense of designing this device in this area is put into doubt.
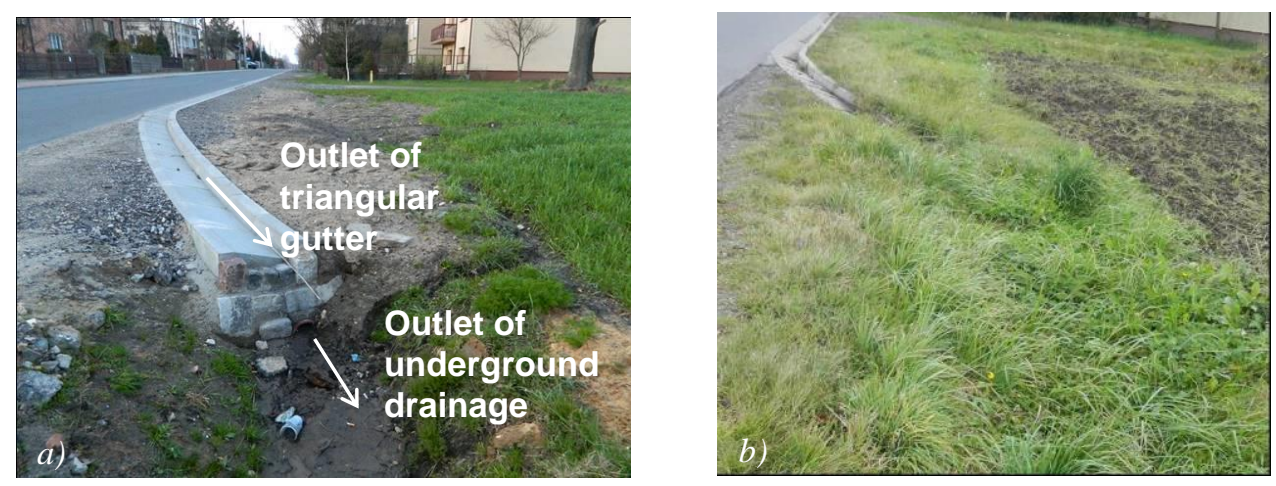

Fig. 9. Loss of dewatering functionality due to lack of maintenance: a) drainage elements one year after construction, b) after three years

Another example of the loss of dewatering efficiency is shown in Fig. 10. Contamination of underground drainage and lack of drainage ditch leads to deposition of rainwater on the surface located in a lowering of the area.

A positive, noticeable effect an increase in the number of treatments involving mowing ditches, cutting off the self-sowing plants in the road nearness, renewing drainage ditches and profiling the swollen roadsides with the use of specialized equipment which could have been observed in recent years (Fig. 11). 


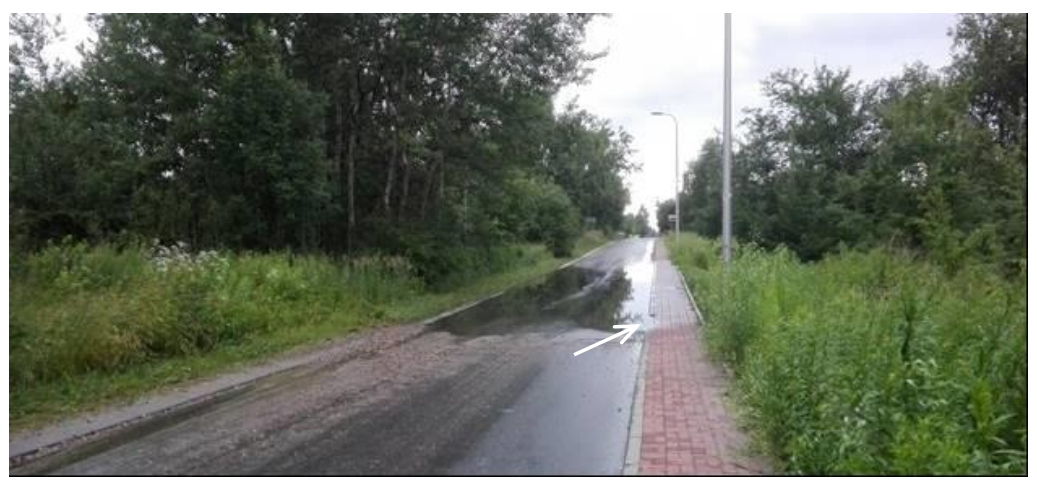

Fig. 10. Deposition of rainwater in a lowering of the area, clogged drainage inlet
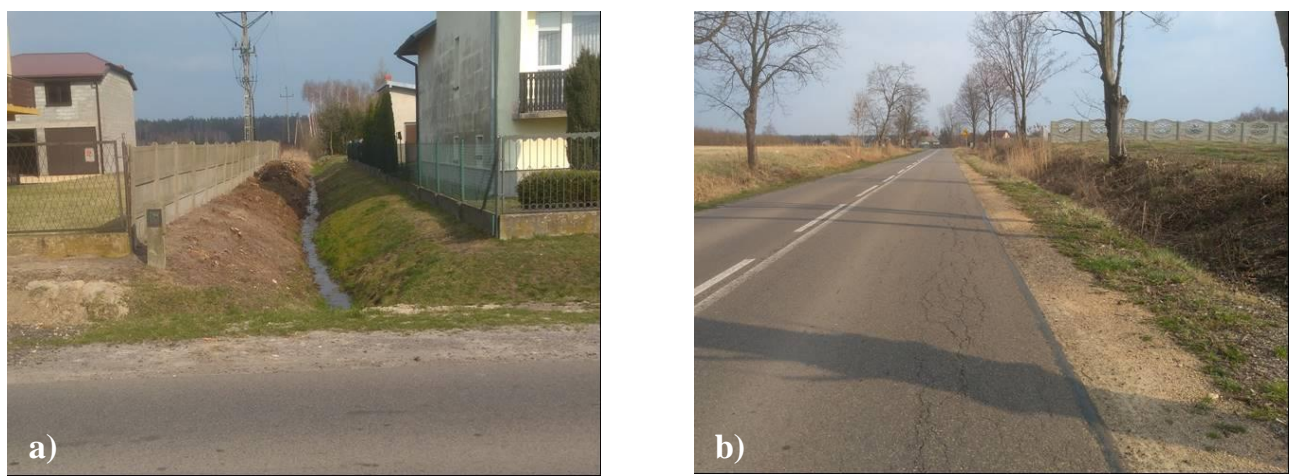

Fig. 11. Treatments related to maintenance of drainage: a) cleaned ditch, b) roadside from figure $7 \mathrm{a}$ after profiling

\section{CONCLUSIONS}

The results of field studies presented in the article indicate that the technical condition of dewatering devices in the example of the commune in the Czestochowa district in recent years has significantly improved, which is shown numerically in the tabular summary of the evaluation results. Repairs and reconstructions carried out in recent years have led to a significant increase in the length of paved roadsides (sidewalks), which is also connected with the implementation of drainage devices. However, some errors were also made during the realization of these tasks. It is worth noticing, for example, the low efficiency of underground drainage in the case of using too small cross-sections of devices or in the case of negligence of systematic cleaning. Also, treatments related to the renovation of ditches and unpaved roadsides are often carried out improperly. These errors generate additional costs in the future. Therefore, they should be eliminated at the stage of investment planning and design - the lack of patency of even one inlet or culvert results in water retention and contamination of all above-located drainage elements.

A positive aspect is the noticeable increase in the awareness of local government institutions in the area of proper road maintenance, including elements of dewatering. Activities such as cleaning ditches and profiling of roadsides are visible, as presented by the improved indicators analyzed in the article. However, local governments have limited financial resources, which is why these activities are still insufficiently realized. 


\section{REFERENCES}

Edel, R., 2000.Odwodnienie dróg. WKiŁ, Warszawa.

Galvão Ribeiro, A.M., Dias Capitãoa, S., Gil Correia, R., 2019. Deciding on maintenance of small municipal roads based on GIS simplified procedures. Case Studies on Transport Policy, 7, 2, 330-337, DOI:10.1016/j.cstp.2019.03.011

Gudelis-Taraszkiewicz, K., 2009. Odwodnienia dróg - bagatelizowany problem? Magazyn Autostrady, 11, 32-33.

https://www.google.com/maps/

Jaarsma, C.F., Van Dijk, T., 2002. Financing local rural road maintenance. Who should pay what share and why? Transportation Research Part A, 36, 507-524.

Kalantari, Z., Briel, A., Lyon, S.W., Olofsson, B, Folkeson, L., 2014. On the utilization of hydrological modelling for road drainage design under climate and land use change. Science of the Total Environment, 475, 97-103, DOI: 10.1016/j.scitotenv.2013.12.114

Karelová, Z., Vranayová, Z., Káposztasová, D., Purcz P., 2013. Rainwater harvesting and its risk assessment. Construction of Optimized Energy Potential, 1(11), 58-65.

Kowacki, M., 2015. Odwodnienia dróg, ulic i mostów. Nowoczesne Budownictwo Inżynieryjne, 5, 48-52.

Majer, S., 2016. Odwodnienie dróg i ulic - zagadnienia techniczne, [Online]. Available: http://www.izbudujemy.pl/artykuly/707/Odwodnienie-drog-i-ulic-8211zagadnienia-techniczne/pdf

Mieszkowski, P., 2006. Kształtowanie wybranych elementów geometrycznych drogi z uwagi na odwodnienie jezdni. Zeszyty Naukowo-Techniczne Stowarzyszenia Inżynierów i Techników Komunikacji w Krakowie, Seria: Materiały Konferencyjne, 77, 11, 147-153.

Respondek, Z., 2017. The Problems of Maintenance of Drainage Devices within Municipal and District Roads, Management Systems in Production Engineering, 25, 2, 100-104, DOI: 10.1515/mspe-2017-0015

System oceny stanu poboczy i odwodnienia dróg (SOPO), 2008. Wytyczne stosowania, GDDKiA, Warszawa.

Szklarzyk, P., 2014. Visual inspection as one of the important elements of the quality control. Production Engineering Archives, 2, 1, 9-11, DOI: 10.30657/pea.2014.02.03

Szyling, Z., Pacześniak, E., 2004. Odwodnienia budowli komunikacyjnych. Oficyna Wydawnicza Politechniki Wrocławskiej, Wrocław, Poland.

Zalecenia projektowania, budowy i utrzymania odwodnienia dróg oraz przystanków komunikacyjnych, 2008. GDDKiA, Warszawa. 